\title{
Adrenal Gland Involvement in Mice with Hereditary Obesity and Diabetes Mellitus
}

\author{
Morphological Studies \\ M. C. Appel, B. A. Schibly, J. A. Kamara, and R. L. Sorenson \\ Department of Anatomy, University of Minnesota School of Medicine, Minneapolis, Minnesota and Departments of Pathology \\ and Anatomy, University of Massachusetts Medical School, Worcester, Massachusetts, USA
}

\begin{abstract}
Summary. The contribution of the adrenal gland to the development of the spontaneous syndrome of obesity and diabetes in Yellow-KK (Y-KK) mice was studied. Six-month old Y-KK mice exhibited hyperadrenocorticism and adrenal cortex enlargement. Light microscopic morphometric studies of Y$\mathrm{KK}$ adrenals revealed an expanded volume of the adrenal cortex resulting from hyperplasia of zona fasciculata and reticularis cells. Ultrastructural studies revealed fewer lipid droplets, increased numbers of mitochondria and a more extensively developed Golgi system within zona fasciculata and reticularis cells. This cytological evidence of enhanced steroid biosynthetic and secretory activity was consistent with increased levels of plasma immunoreactive corticosterone. Structural and functional abnormalities of Y-KK adrenals were preceded by the development of obesity, hyperglycaemia and hyperinsulinaemia. It is unlikely, therefore, that the adrenal plays a causal role in the syndrome's pathogenesis, although, hyperadrenocorticism may be in part responsible for an exacerbation of the observed phenomena.
\end{abstract}

Key words: Yellow-KK mice, diabetes, obesity, adrenal cortex hyperplasia, corticosterone.

Structural and functional abnormalities of the adrenal cortex are frequently associated with obesity and maturity-onset diabetes mellitus. Enlargement of the adrenal cortex [1] and hypercortisolism have been reported in obese humans with demonstrated insulin resistance [2,3]. In addition, individuals with Cushing's syndrome have a marked tendency to develop diabetes [4].

Adrenal gland dysfunction has also been reported in laboratory animal models exhibiting hereditary obesity and diabetes $[5,6,7]$. Evidence suggesting a contributory role of the adrenal in these animal syndromes is based on observations of adrenal enlargement, hyperadrenocorticism and improvement of adiposity, hyperglycaemia and glucose tolerance following adrenalectomy $[8,9,10]$.

This report describes an examination of the role of the adrenal gland in the genesis of the inherited obesity-hyperglycaemia syndrome displayed by male Yellow-KK (Y-KK) hybrid mice. Y-KK mice can be easily identified at birth and consistently develop obesity, glucose intolerance, accelerated gluconeogenesis, insulin resistance and hyperplasia of the pancreatic islets of Langerhans [11-14]. Because of the precision with which one can predict genotypically susceptible individuals and the uniformity in the phenotype expressed, Y-KK mice are useful models for evaluating the temporal relationship between the above disorders and structural/functional changes in the adrenal gland. Adrenals obtained from Y-KK mice at various ages were examined by electron microscopy and were subjected to light-microscopical morphometric analysis.

\section{Materials and Methods}

Yellow-KK mice were derived from crosses between lethal yellow mice $\left(\mathrm{A}^{\mathrm{y} / \mathrm{a}} \times \mathrm{C} 57 \mathrm{Bl} / 6 \mathrm{~J}\right)$ (Jackson Laboratory, Bar Harbor, Maine) and Toronto-KK hybrid $(\mathrm{KK} \times \mathrm{C} 57 \mathrm{Bl} / 6 \mathrm{~J})$ mice (Upjohn Company, Kalamazoo, Michigan). From these initial breeding stocks, subsequent colonies of these animals were established (University of Minnesota, Minneapolis, Minnesota). Male Toronto-KK hybrid mice were crossed with female lethal yellow mice and the resulting progeny included animals with black, white or yellow coat colours. Only males with a yellow coat colour were selected for the experiments. C57 Bl/6J mice (Jackson Laboratory) of the same age and sex were used as controls rather than black or white littermates because the latter frequently exhibited 
mild hyperglycaemia and obesity. Furthermore, the C57Bl/6J background is incorporated into the genome of both parent mice. Animals were provided with water and Purina Mouse Chow ad libitum.

\section{Blood Analysis and Tissue Processing}

Blood samples were collected between 0900 and 1100 hours from the orbital venous sinus and assayed for glucose [15], plasma immunoreactive insulin [16] and plasma immunoreactive corticosterone $[14,17]$. Crystalline murine insulin (NOVO, Copenhagen, Denmark) was used in standards. All blood samples were obtained within thirty seconds after the initial physical contact with the animal. Mice were sacrificed by cervival dislocation and the adrenals were trimmed free of non-glandular tissues and weighed on a torsion balance having a unit sensitivity of $0.1 \mathrm{mg}$. The adrenal glands were then fixed in Zenker-formol solution [18] and paraffin sections stained with haematoxylin and eosin.

Twelve $\mathrm{Y}-\mathrm{KK}$ and six $\mathrm{C} 57 \mathrm{Bl} / 6 \mathrm{~J}$ mice of various ages were selected for electron microscopical studies. Animals were anaesthetized with pentobarbitone sodium solution $(10 \mathrm{mg} / 100 \mathrm{~g}$ body weight), then perfused via cardiac canulae with Ringer's lactate solution containing $1 \mathrm{U} / \mathrm{ml}$ each of sodium heparin and procaine hydrochloride. Tissues were subsequently perfused with $0.1 \mathrm{M}$ potassium phosphate buffered paraformaldehyde $(0.1 \mathrm{~g} / \mathrm{l})$ and glutaraldehyde $(0.125 \mathrm{~g} / 1)$ containing $10 \mathrm{~g} / 1$ dextran $\mathrm{T}-40$ (Pharmacia) and $0.555 \mathrm{~g} / 1 \mathrm{CaCl}_{2}(\mathrm{pH} 7.4)$. Adrenal segments were subsequently postfixed with $0.2 \mathrm{~g} / 1$ collidine-buffered ( $\mathrm{pH}$ 7.2) osmium tetroxide, dehydrated in a graded series of ethanol solutions and embedded in either Spurr or epon-araldite resins. Thin sections were stained sequentially with uranyl acetate and lead citrate [19] and examined with either an RCA EMU-3G or a Philips 301 electron microscope.

\section{Morphometrical Analysis}

Adrenal glands were sectioned at $5 \mu$ increments and every tenth section subjected to planimetric analysis. Microscopic sections were projected on drawing paper at a total magnification of X 115 and the external borders of the cortical and inner medullary zones were traced. The relative percent volumes of the adrenal components were determined using an OTT compensating planimeter having a unit range of 0.01 square inches and were calculated by the method of Eranko [20].

To determine if this sampling procedure was adequate for estimating total adrenal volume, a preliminary study was initiated. An entire adrenal gland was sectioned at $5 \mu$ intervals and the area of each section determined planimetrically. The actual volume $\left(\mathrm{V}_{\mathrm{A}}\right)$ was then determined by:

$\mathrm{V}_{\mathrm{A}}=\mathrm{X}_{\mathrm{i}-\mathrm{N}} \cdot \mathrm{T}=\mathrm{X}_{1}+\mathrm{X}_{2}+\mathrm{X}_{3} \ldots \mathrm{X}_{\mathrm{N}} \cdot \mathrm{T}$

where $X_{i-N}$ is the total summated areas of all tissue sections and $T$ is the section thickness. Similarly, the relative volume $\left(V_{R}\right)$ obtained from every tenth section was determined as described above and the percent ratio of relative/actual volume was calculated by:

$\frac{V_{R}}{V_{A}} \times 100$

Analysis of ten such measurements yielded ratios differing by less than $1.0 \%$. In addition, the correlation between adrenal weight and the corresponding relative volume determined from measurements of each tenth section were tested by linear regression and expressed as the coefficient of correlation (r) [20]. Mechanical errors associated with planimetric measurements were determined by making multiple area determinations of a single section. The values obtained from these measurements differed by less than $0.1 \%$ of the mean area determination.

\section{Statistical Analysis}

Values obtained from biochemical and morphometrical analysis are expressed as means \pm standard deviation of the mean. Mean values between experimental and control animals were compared by Student's t-test. Differences with $p$ values less than 0.05 were considered significant.

\section{Results}

\section{General Characteristics}

A comparison of body weights, blood glucose, plasma immunoreactive insulin and plasma immunoreactive corticosterone between $\mathrm{C} 57 \mathrm{Bl} / 6 \mathrm{~J}$ and $\mathrm{Y}-\mathrm{KK}$ mice at various ages is illustrated in Table 1. These variables were normal in $\mathrm{Y}-\mathrm{KK}$ mice at one month of age but increased body weight, hyperglycaemia and hyperinsulinaemia were present at three months. These abnormalities were most pronounced in six-month old Y-KK mice but subsequently declined in severity. Plasma immunoreactive corticosterone levels from $\mathrm{Y}-\mathrm{KK}$ mice were normal at one and three-months of age, but were more than twice control levels at six and twelve-months.

\section{Adrenal Weight Determinations and Planimetric Analysis}

Adrenal gland weights of $\mathrm{C} 57 \mathrm{Bl} / 6 \mathrm{~J}$ and $\mathrm{Y}-\mathrm{KK}$ mice at various ages are illustrated in Table 1 . Adrenal weights of $\mathrm{C} 57 \mathrm{Bl} / 6 \mathrm{~J}$ mice were similar at all the ages studied. Y-KK and control adrenal weights were comparable at one month of age. Thereafter, Y-KK adrenal glands were significantly heavier. When adrenal weights are expressed as percent of total body weight, there were no differences observed between Y-KK and controls at one and three-months of age. However, when six and twelve-month old animals were compared, Y-KK adrenals comprised a significantly greater percentage of the total body weight than controls.

Figure 1 depicts the relationship between adrenal weights and the relative area obtained from planimetric measurements. A linear relationship was demonstrated between planimetric adrenal area measurements and the corresponding adrenal weights. Linear correlation coefficients (r) were calculated independently for $\mathrm{C} 57 \mathrm{Bl} / 6 \mathrm{~J}$ and $\mathrm{Y}$-KK mice and were found to be 0.973 and 0.988 respectively. 
Table 1. General characteristics of $\mathrm{C} 57 \mathrm{Bl} / 6 \mathrm{~J}$ and Yellow-KK mice at various ages

\begin{tabular}{|c|c|c|c|c|c|c|c|c|}
\hline Animal & (n) & $\begin{array}{l}\text { Age } \\
\text { (months) }\end{array}$ & $\begin{array}{l}\text { Body } \\
\text { weight } \\
\text { (g) }\end{array}$ & $\begin{array}{l}\text { Blood } \\
\text { glucose } \\
(\mathrm{mg} / \mathrm{dl})\end{array}$ & $\begin{array}{l}\text { Plasma } \\
\text { insulin } \\
(\mu \mathrm{U} / \mathrm{ml})\end{array}$ & $\begin{array}{l}\text { Plasma } \\
\text { corticos- } \\
\text { terone } \\
(\mu \mathrm{g} / \mathrm{dl})\end{array}$ & $\begin{array}{l}\text { Adrenal }^{\mathrm{a}} \\
\text { weight } \\
\text { (mg) }\end{array}$ & $\begin{array}{l}\text { Adrenal } \\
\text { weight } \\
\text { (\% Body weight) }\end{array}$ \\
\hline $\mathrm{C} 57 \mathrm{Bl} / 6 \mathrm{~J}$ & (10) & 1 & $13.8 \pm 1.1$ & $128 \pm 9$ & $27 \pm 4$ & $12.8 \pm 4.7$ & $1.8 \pm 0.2$ & $0.013 \pm 0.002$ \\
\hline Yellow-KK & (10) & 1 & $13.9 \pm 1.2$ & $114 \pm 18$ & $32 \pm 9$ & $11.4 \pm 4.2$ & $1.8 \pm 0.3$ & $0.013 \pm 0.002$ \\
\hline $\mathrm{C} 57 \mathrm{Bl} / 6 \mathrm{~J}$ & (10) & 3 & $27.9 \pm 1.2$ & $134 \pm 14$ & $43 \pm 10$ & $10.2 \pm 4.4$ & $2.1 \pm 0.2$ & $0.008 \pm 0.001$ \\
\hline Yellow-KK & (10) & 3 & $\begin{array}{l}41.2 \pm 2.8 \\
(0.001)^{\mathrm{b}}\end{array}$ & $\begin{array}{l}208 \pm 62 \\
(0.05)\end{array}$ & $\begin{array}{l}876 \pm 403 \\
(0.001)\end{array}$ & $15.6 \pm 7.2$ & $\begin{array}{l}2.9 \pm 0.6 \\
(0.001)\end{array}$ & $0.007 \pm 0.001$ \\
\hline $\mathrm{C} 57 \mathrm{~B} 1 / 6 \mathrm{~J}$ & (10) & 6 & $34.5 \pm 2.0$ & $126 \pm 17$ & $38 \pm 8$ & $12.9 \pm 3.2$ & $1.8 \pm 0.4$ & $0.005 \pm 0.002$ \\
\hline Yellow-KK & (10) & 6 & $\begin{array}{l}51.9 \pm 3.3 \\
(0.001)\end{array}$ & $\begin{array}{l}296 \pm 73 \\
(0.001)\end{array}$ & $\begin{array}{l}3664 \pm 1291 \\
(0.001)\end{array}$ & $\begin{array}{l}28.4 \pm 6.3 \\
(0.01)\end{array}$ & $\begin{array}{l}3.7 \pm 0.8 \\
(0.001)\end{array}$ & $0.008 \pm 0.001$ \\
\hline $\mathrm{C} 57 \mathrm{Bl} / 6 \mathrm{~J}$ & (10) & 12 & $34.8 \pm 2.8$ & $139 \pm 12$ & $44 \pm 5$ & $11.6 \pm 3.3$ & $2.1 \pm 0.4$ & $0.007 \pm 0.001$ \\
\hline Yellow-KK & (10) & 12 & $\begin{array}{l}47.6 \pm 2.7 \\
(0.001)\end{array}$ & $154 \pm 28$ & $\begin{array}{l}1275 \pm 564 \\
(0.001)\end{array}$ & $\begin{array}{l}24.9 \pm 6.8 \\
(0.05)\end{array}$ & $\begin{array}{l}3.3 \pm 0.8 \\
(0.001)\end{array}$ & $0.008 \pm 0.001$ \\
\hline
\end{tabular}

Values represent means \pm 1 standard deviation

a Adrenal weight determinations are based upon values obtained using both adrenals from each animal

b Level of significance of the difference as determined from the Student's t-test

When the above regression analysis was made using combined data points from both $\mathrm{C} 57 \mathrm{Bl} / 6 \mathrm{~J}$ and $\mathrm{Y}$ KK mice, the correlation coefficient was found to be 0.991 . The slopes of the regression lines did not differ statistically.

The data obtained from quantitative planimetric analysis of adrenal tissue sections are presented in Table 2. Significant quantitative differences were not observed between adrenals from one-month old C57 Bl/6J and Y-KK mice. However, significant differences in the relative tissue composition of the adrenal cortex were observed between these animal groups at all subsequent ages. The percent volume of the adrenal cortex was highest in both one-month old $\mathrm{C} 57 \mathrm{Bl} / 6 \mathrm{~J}$ and $\mathrm{Y}-\mathrm{KK}$ mice. After one month of age, the percent volume of the adrenal cortex declined in both groups but showed the largest reduction in control mice. Although relative weights of adrenal medulla did not differ significantly between C57Bl/ $6 \mathrm{~J}$ and $\mathrm{Y}-\mathrm{KK}$ mice at any of the ages studied, the relative weights of the adrenal cortex were significantly greater in three, six and twelve-month old Y$\mathrm{KK}$ mice. Therefore, the increased adrenal weights observed in Y-KK mice of these ages resulted primarily from an expanded volume of adrenal cortical tissues rather than from proportionate increases in the volume of both cortical and medullary tissue components.

\section{Light Microscopy}

Adrenal medulla and zona glomerulosa tissues from C57B1/6J and Y-KK mice were morphologically normal and indistinguishable when examined by light and electron microscopy. The fetal $\mathrm{X}$-zones were

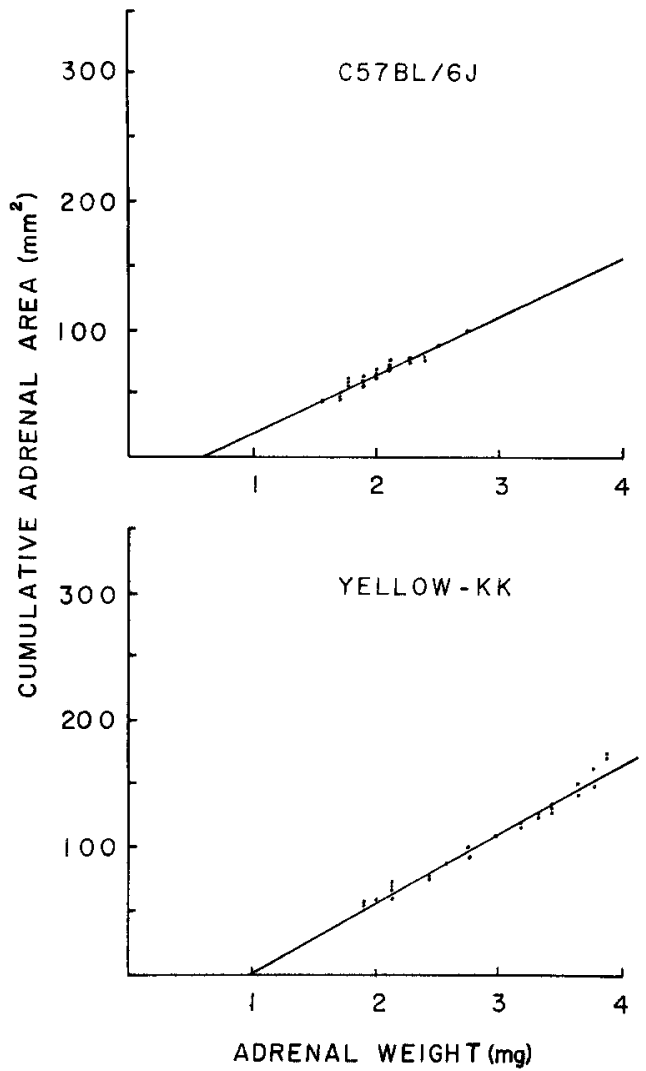

Fig. 1. Relationship between adrenal weight and adrenal area as determined by planimetry in $\mathrm{C} 57 \mathrm{Bl} / 6 \mathrm{~J}$ and Yellow-KK mice. Coefficient of correlation $(\mathrm{r})=0.973$ for $\mathrm{C} 57 \mathrm{Bl} / 6 \mathrm{~J}$ and 0.988 for Yellow-KK mice

absent in adrenals of both mouse groups at one month of age and the constituent morphological zones could be readily identified. However, differentiation of inner zona fasciculata cells from zona reticularis cells was difficult in all age groups. 
Table 2. Relative weights and percent volumes of the adrenal cortex and adrenal medulla in $\mathrm{C} 57 \mathrm{Bl} / 6 \mathrm{~J}$ and Yellow-KK mice

\begin{tabular}{|c|c|c|c|c|c|c|}
\hline Animal & (n) & $\begin{array}{l}\text { Age } \\
\text { (months) }\end{array}$ & $\begin{array}{l}\text { Relative } \\
\text { weight } \\
\text { cortex } \\
(\mathrm{mg})\end{array}$ & $\begin{array}{l}\text { Relative } \\
\text { weight } \\
\text { medulla } \\
\text { (mg) }\end{array}$ & $\begin{array}{l}\text { Percent }^{\mathrm{a}} \\
\text { volume } \\
\text { cortex }\end{array}$ & $\begin{array}{l}\text { Percent } \\
\text { volume } \\
\text { medulla }\end{array}$ \\
\hline $\mathrm{C} 57 \mathrm{Bl} / 6 \mathrm{~J}$ & $(5)$ & 1 & $1.6 \pm 0.2$ & $0.3 \pm 0.1$ & $84.5 \pm 1.9$ & $15.5 \pm 1.9$ \\
\hline Yellow-KK & (5) & 1 & $1.8 \pm 0.2$ & $0.3 \pm 0.1$ & $86.0 \pm 2.3$ & $14.0 \pm 2.3$ \\
\hline $\mathrm{C} 57 \mathrm{Bl} / 6 \mathrm{~J}$ & (5) & 3 & $1.6 \pm 0.3$ & $0.4 \pm 0.1$ & $78.5 \pm 1.5$ & $21.5 \pm 1.5$ \\
\hline Yellow-KK & (5) & 3 & $\begin{array}{l}2.4 \pm 0.5 \\
(0.02)^{\mathrm{b}}\end{array}$ & $0.6 \pm 0.2$ & $80.9 \pm 3.8$ & $19.1 \pm 3.8$ \\
\hline $\mathrm{C} 57 \mathrm{Bl} / 6 \mathrm{~J}$ & (5) & 6 & $1.4 \pm 0.1$ & $0.4 \pm 0.1$ & $75.7 \pm 3.9$ & $24.3 \pm 3.9$ \\
\hline Yellow-KK & (5) & 6 & $\begin{array}{l}3.2 \pm 0.4 \\
(0.001)\end{array}$ & $0.7 \pm 0.3$ & $\begin{array}{l}82.6 \pm 2.6 \\
(0.01)\end{array}$ & $\begin{array}{l}17.4 \pm 2.6 \\
(0.01)\end{array}$ \\
\hline $\mathrm{C} 57 \mathrm{Bl} / 6 \mathrm{~J}$ & $(5)$ & 12 & $1.7 \pm 0.3$ & $0.5 \pm 0.1$ & $77.4 \pm 2.8$ & $22.6 \pm 2.8$ \\
\hline Yellow-KK & (5) & 12 & $\begin{array}{l}2.8 \pm 0.3 \\
(0.001)\end{array}$ & $0.6 \pm 0.1$ & $\begin{array}{l}81.4 \pm 2.2 \\
(0.05)\end{array}$ & $\begin{array}{l}18.6 \pm 2.2 \\
(0.05)\end{array}$ \\
\hline
\end{tabular}

Values represent means \pm 1 standard deviation

a Percent volume was calculated according to the following: $\frac{\text { relative volume }(\mathrm{Vr}) \text { tissue component }}{\text { relative Volume }(\mathrm{Vr}) \text { total adrenal }} \times 100$

${ }^{b}$ Level of significance of the difference as determined from the Student's t-test

By light microscopy, the structural variations between $\mathrm{C} 57 \mathrm{Bl} / 6 \mathrm{~J}$ and $\mathrm{Y}-\mathrm{KK}$ adrenals appeared to result from quantitative rather than qualitative differences. Adrenals of six and twelve-month old YKK mice exhibited an expanded cortical zone due to hyperplasia of component zona fasciculata and reticularis cells (Figures $2 a$ and $2 b$ ). Reduced numbers of intracellular lipid droplets were also observed, particularly in zona fasciculata and reticularis cells of six-month old Y-KK mice (Figures $2 \mathrm{c}$ and $2 \mathrm{~d}$ ). The degree of lipid depletion was variable but most pronounced at the inner cortical region. Foci of amorphous eosinophilic deposits were observed at the cortico-medullary junction of adrenals from both $\mathrm{C} 57 \mathrm{Bl} / 6 \mathrm{~J}$ and $\mathrm{Y}-\mathrm{KK}$ mice at twelve months of age. These deposits stained positively after treatment with periodic acid-Schiff (PAS) stain and were most abundant in $\mathrm{Y}-\mathrm{KK}$ mice.

\section{Electron Microscopy}

Ultrastructural differences between adrenal glands of $\mathrm{C} 57 \mathrm{Bl} / 6 \mathrm{~J}$ and $\mathrm{Y}-\mathrm{KK}$ mice were not encountered before six months of age. Increased numbers of zona fasciculata and zona reticularis cells were seen in sixmonth old Y-KK mice. These cells frequently possessed a more extensively developed Golgi system and contained variably fewer intracellular lipid deposits and increased numbers of mitochondria than corresponding cells from control mice (Figures $3 \mathrm{a}$ and $3 \mathrm{~b}$ ). However, gross differences in basement membrane thickness, surface volume of mitochondrial cristae or volume of smooth endoplasmic reticulum were not observed between zona fasciculata and zona reticularis cells of $\mathrm{C} 57 \mathrm{Bl} / 6 \mathrm{~J}$ and Y-KK mice.

Adrenal cortical cells from twelve-month old $\mathrm{C} 57 \mathrm{Bl} / 6 \mathrm{~J}$ and $\mathrm{Y}-\mathrm{KK}$ mice showed comparable ultrastructural features. Moderately reduced numbers of intracellular lipid droplets were occasionally observed in Y-KK zona fasciculata and reticularis cells. The magnitude of these intracellular lipid depletions, however, was never equal to that observed in Y-KK mice at six months of age. Aggregates of amorphous materials having different electron densities were observed at the juxta medullary borders of six and twelve month old Y-KK and control mice. These deposits were most abundant in YKK mice and appeared to be the ultrastructural equivalent of the PAS-positive materials noted by light microscopy. Fibrillar substances organised as circular whorls and resembling amyloid were dispersed throughout the matrix of these deposits.

\section{Discussion}

The adrenal glands of Y-KK mice demonstrate functional and morphological alterations which may play a role in the obesity and diabetes mellitus observed in these animals. By six months of age, Y-KK mice exhibit elevated plasma immunoreactive corticosterone levels. Since the absolute plasma corticosterone concentration is determined by the rate of steroid synthesis and secretion, the degree of peripheral binding and the rate of corticosterone 


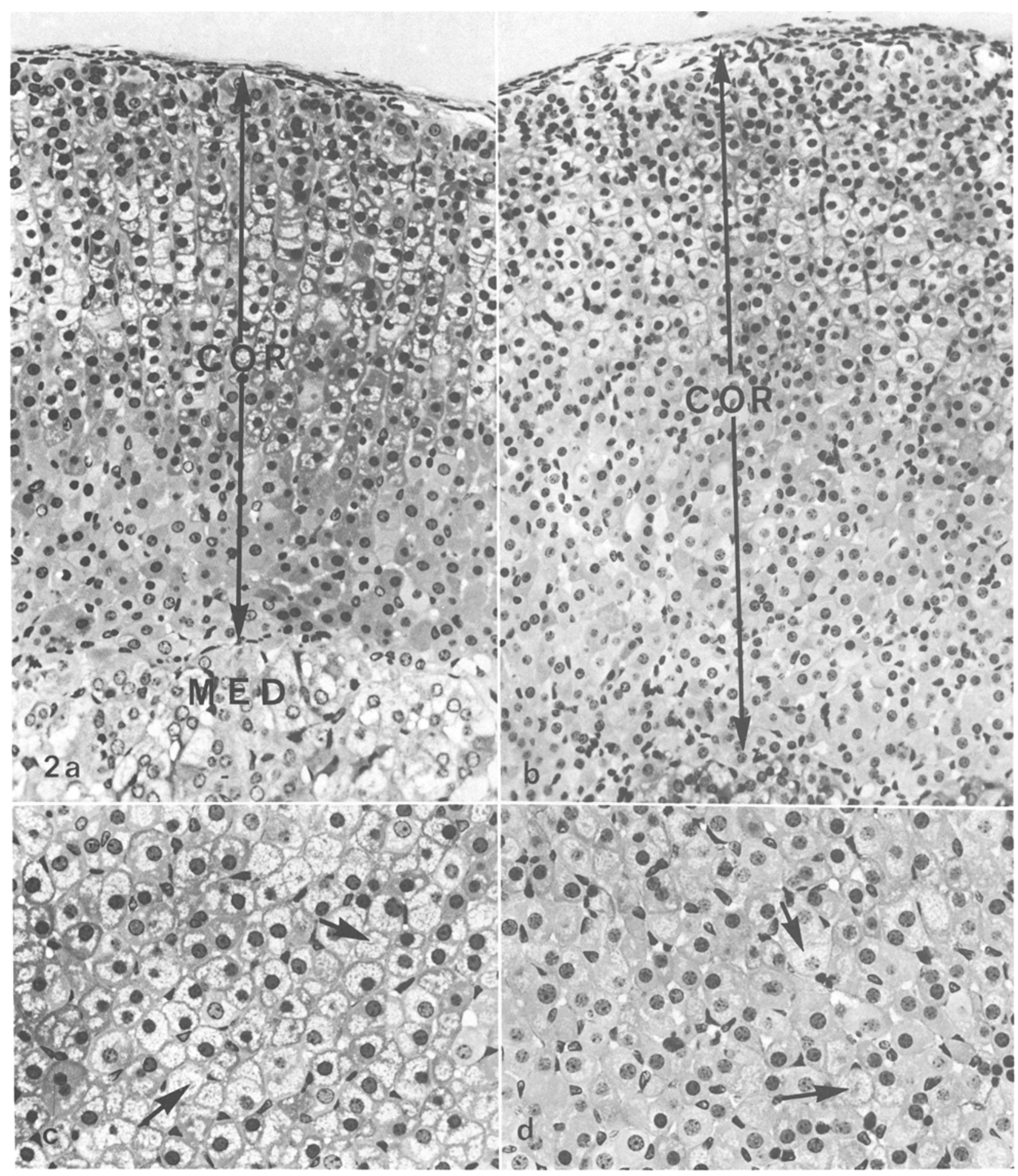

Fig. 2. Adrenal glands from six-month old $\mathrm{C} 57 \mathrm{~B} 1 / 6 \mathrm{~J}$ and Yellow-KK mice sectioned at the equatorial plane. a Adrenal from $\mathrm{C} 57 \mathrm{Bl} / 6 \mathrm{~J}$ mouse showing normal extent of adrenal cortex (COR) and medulla (MED). H \& E stain $\times 450$. b Hyperplasia of the adrenal cortex is evident from the Yellow-KK mouse. $\mathrm{H} \& \mathrm{E}$ stain $\times 450$. c Zona fasciculata cells from C57Bl/6J mouse. H \& E stain $\times 600$. d Reduced amounts of intracellular lipid are seen in zona fasciculata cells from Yellow-KK mouse. H \& E stain. $\times 600$ 


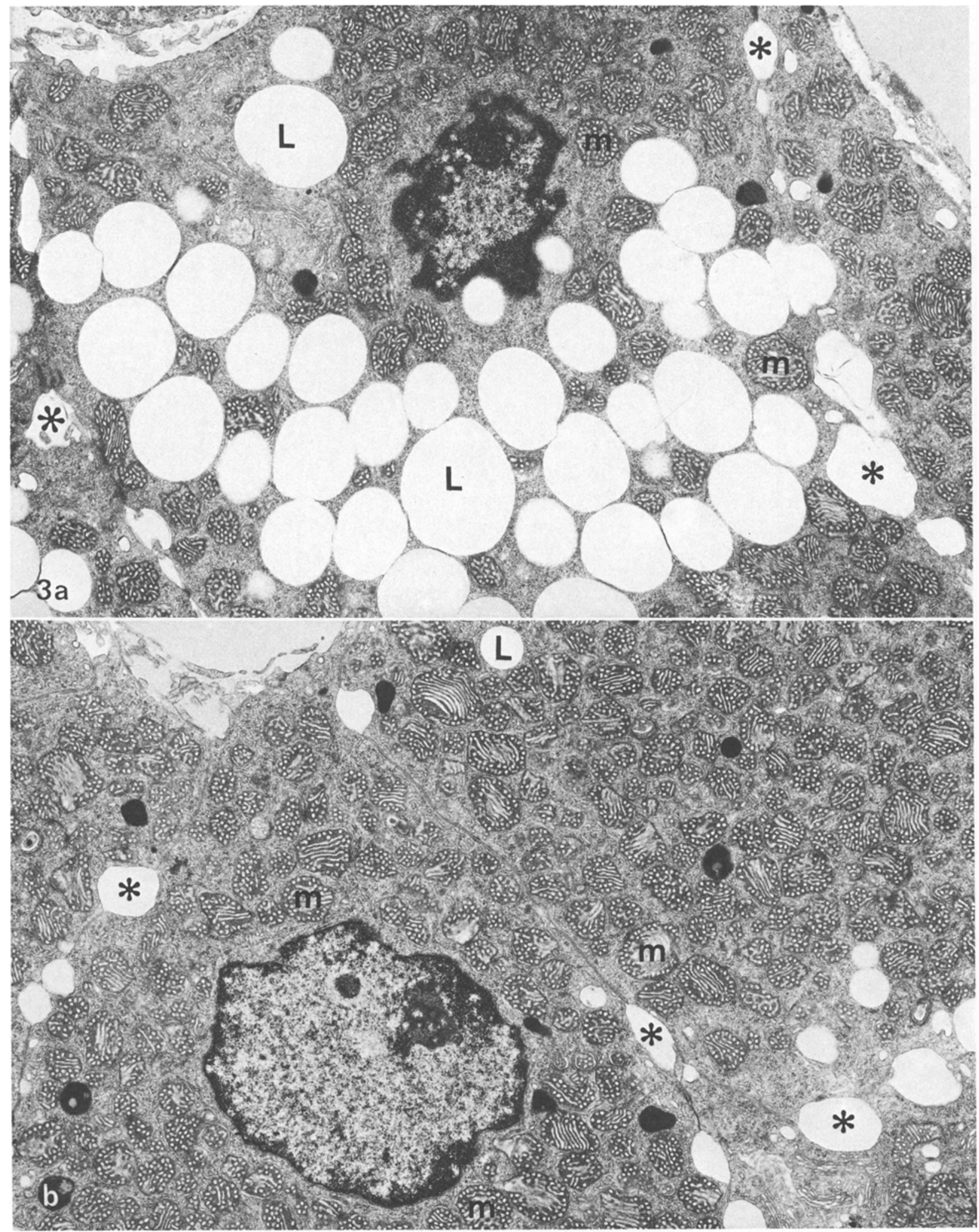

Fig. 3. a Electron micrograph showing zona fasciculata cells from six-month old $\mathrm{C} 57 \mathrm{Bl} / 6 \mathrm{~J}$ mouse. $\times 8.600 \mathrm{~b}$ Zona fasciculata cells from Yellow-KK mouse contain fewer intracellular lipid droplets (L) and increased numbers of vesiculotubular mitochondria (M). * = intercellular spaces. $\times 8.600$ 
degradation, it is possible that aberrations of any of these processes can produce increased plasma corticosterone levels. Little data have been reported attributing increased corticosterone levels to defective peripheral binding with transcortin or to a subnormal rate of corticosterone clearance from the blood. These indices were investigated in obesehyperglycaemic mice displaying hyperadrenocorticism $[6,21]$ and were not found to be responsible for elevated plasma immunoreactive corticosterone levels.

The data reported above suggest that the elevated plasma immunoreactive corticosterone levels resulted from an increased rate of corticosterone biosynthesis and release. In six-month old Y-KK mice, increased corticosterone levels are coincident with adrenal gland enlargement. Light microscopic examination and planimetric analysis of Y-KK adrenals indicate that this enlargement results from hyperplasia of zona fasciculata and zona reticularis cells. These cells also exhibit several ultrastructural features which are characteristic of enhanced steroid production and secretion - i. e.: increased numbers of mitochondria and reduced numbers of intracellular lipid droplets. Similar morphological changes have been described in zona fasciculata cells from humans with adrenal cortical hyperplasia and from animals chronically treated with excessive concentrations of adrenocorticotrophic hormone (ACTH) [22, 23].

The significance of the other morphological alterations observed in adrenal glands of Y-KK mice displaying hyperadrenocorticism is less clear. Cells from the zona reticularis of these mice contain fewer intracellular lipid droplets and increased numbers of mitochondria. Since it is known that cells from this portion of the adrenal cortex produce sex steroids or sex steroid precursors [24], defects associated with increased sex steroid secretion might have been expected. Male Y-KK mice maintained normal fertility and androgen related abnormalities were not observed. The amorphous eosinophilic materials localised at the juxta-medullary border resembled amyloid when examined by electron microscopy. However, definitive identification of this material would require additional histochemical analysis. Amyloidosis has been reported in old mice [25] and in obese-hyperglycaemic mice exhibiting hyperadrenocorticism [8]. Since these deposits were observed in adrenals from both $\mathrm{C} 57 \mathrm{Bl} / 6 \mathrm{~J}$ and $\mathrm{Y}-\mathrm{KK}$ mice and only in twelve-month old animals, the biological significance of adrenal gland amyloidosis was questionable.

Little information is available concerning the aetiological factors responsible for adrenal cortical hyperplasia. Enlargement of the adrenal cortex has been reported in human obesity [1] and in numerous strains of spontaneously obese and diabetic laboratory animals $[5,8]$. Adrenal cortical hyperplasia presumably results from chronic stimulation of the adrenal by $\mathrm{ACTH}$, although the biochemical defects which precipitate increased plasma ACTH levels are unknown. Although plasma ACTH levels were not measured in Y-KK mice, other studies have demonstrated elevated concentrations of plasma immunoreactive corticosterone during basal conditions and after stimulation with ACTH and stress [14]. These observations suggest that Y-KK adrenals have an increased functional capacity for corticosterone synthesis and secretion.

Structural and functional abnormalities of Y-KK adrenals are preceded by obesity, hyperglycaemia and hyperinsulinaemia. Therefore, it is unlikely that adrenal gland disorders play a primary role in the syndrome's pathogenesis. Because excessive plasma corticosterone levels have been shown to produce adiposity [26], glucose intolerance [4], insulin resistance [27] and pancreatic beta cell hyperplasia [26, 28 ], it is likely that hyperadrenocorticism exacerbates these pre-existing metabolic abnormalities. It is of interest that elevated plasma corticosterone levels have been reported in obese-hyperglycaemic mice at ages which coincide with the development of adiposity and hyperglycaemia $[6,29]$. In contrast, hypersecretion of corticosteroid and adrenal cortical hyperplasia have not been observed [5] in all animal models displaying spontaneous obesity and diabetes mellitus. The dispartiy observed in the development and significance of adrenal gland dysfunction in these animals models underscores the genetic variability and complex multifactorial aetiology of the murine obesity-hyperglycaemia syndromes.

Acknowledgements. Supported in part by Diabetes Training Grant \# AM 05127.

We gratefully acknowledge the assistance of Ms. Claudia Berger and Deborah Schmidt in the preparation of this manuscript. Appreciation is also extended to Mr. Peter Healy for his expert photographic assistance and to Dr. Arthur Like for his constructive comments.

\section{References}

1. Szenas, P., Pattee, C. J.: Studies of adrenocortical function in obesity. J. Clin. Endocrinol. Metab. 19, 344-350 (1959)

2. Schteingart, D. E., Conn, J.W.: Cortisol secretion turnover. and metabolism in obesity. In: Physiopathology of adipose tissue. Vague, J., Denton, R. M. (Eds.). Amsterdam: Excerpta Medica Foundation 1969

3. Lentle, B. C., Thomas, J. P.: Adrenal function and the complications of diabetes mellitus. Lancet 1964 II, 544-549

4. Thorn, G. W., Renold, A. E., Cahill, G. F.: The adrenal and 
diabetes. Some interactions and intercorrelations. Diabetes $\mathbf{8}$, 337-351 (1959)

5. Bray, G. A., York, D. A.: Genetically transmitted obesity in rodents. Physiol. Rev. 51, 598-646 (1971)

6. Naeser, P.: Function of the adrenal cortex in obese-hyperglycemic mice (gene symbol ob). Diabetologia 10, 449-453 (1974)

7. Coleman, D. L., Burkart, D. L.: Plasma corticosterone concentrations in diabetic (db) mice. Diabetologia 13, 25-26 (1977)

8. Naeser, P.: Structure of the adrenal glands in mice with the obesehyperglycemic syndrome (gene symbol ob). Acta Pathol. Microbiol. Scand. [A] 83, 120-126 (1975)

9. Solomon, J., Mayer, J.: The effect of adrenalectomy on the development of the obese-hyperglycemic syndrome in $\mathrm{ob} / \mathrm{ob}$ mice. Endocrinology 93, 510-513 (1973)

10. Solomon, J., Bradwin, G., Cocchia, M. A., Coffey, D., Condon, T., Garrity, W., Grieco, W.: Effects of adrenalectomy on body weitht and hyperglycemia in five months old ob/ob mice. Horm. Metab. Res. 9, 152-156 (1977)

11. Iwatsuka, H., Shino, A., Suzuoki, Z.: General survey of diabetic features of yellow-KK mice. Endocrinol. Jpn. 17, 25-33 (1970)

12. Taketomi, S., Tsuda, M., Matsuo, T., Iwatsuka, H., Suzuoki, Z.: Alterations of hepatic enzyme activities in KK and yellowKK mice with various diabetic states. Horm. Metab. Res. 5, 333-339 (1973)

13. Shino, A., Iwatsuka, H.: Morphological observations on pancreatic islets of spontaneously diabetic mice, yellow-KK. Endocrinol. Jpn. 17, 459-476 (1970)

14. Appel, M. D.: Characterization of diabetes mellitus in the yellow-KK mouse. Ph. D. Dissertation, University of Minnesota, 1-185 (1977)

15. Hoffman, W. S.: A rapid photoelectric method for the determination of glucose in blood and urine. J. Biol. Chem. 120, 51-55 (1937)

16. Desbuquois, B., Aurbach, G. D.: Use of polyethylene glycol to separate free and antibody-bound peptide hormones in radioimmunoassays. J. Clin. Endocrinol. Metab. 33, 732-738 (1971)

17. Endocrine Sciences Technical Bulletin B21-42. Tarzana, California

18. Humasson, G. L.: Animal tissue techniques, p. 151. San Francisco: W. H. Freeman and Company 1962
19. Reynolds, E. S.: The use of lead citrate at high $\mathrm{pH}$ as an electronopaque stain in electron microscopy. J. Cell. Biol. 17, 208-212 (1963)

20. Eranko, O.: Quantitative methods in histology and microscopic histochemistry, p. 57. Basle, New York: S. Karger Publishers 1955

21. Naeser, P.: Disappearance of ${ }^{3} \mathrm{H}$-corticosterone from the serum of obese-hyperglycemic mice (gene symbol ob). Acta Physiol. Scand. 93, 10-14 (1975)

22. Nussdorfer, G. G., Mazzocchi, G.: A sterologic study of the effects of ACTH and cyclic-3', 5'-AMP on adrenocortical cells of intact and hypophysectomized rats. Lab. Invest. 26, 45-52 (1972)

23. Malamed, S. J.: Ultrastructure of the mammalian adrenal cortex in relation to secretory function. In: Handbook of Physiology. Endocrinology VI, 25-39 (1974)

24. Idelman, S.: Ultrastructure of the mammalian adrenal cortex. Int. Rev. Cytol. 27, 181-281 (1970)

25. Thung, P. J.: Senile amyloidosis in mice. Gerontologia 1 , 259-279 (1957)

26. Hausberger, F. X., Ramsay, A. J.: Islet-hypertrophy in obesity of mice bearing ACTH-secreting tumors. Endocrinology 65, 165-171 (1959)

27. Kahn, C. R., Goldfine, I. D., Neville, D. M., Jr., Roth, J., Bates, R.W., Garrison, M.M.: Insulin receptor defect: A major factor in the insulin resistance of glucocorticoid excess. Endocrinology 93, 168 (1973)

28. Wellman, K.F., Volk, B.W.: Fine structure of pancreas in cortisonetreated guinea pigs and rabbits. Arch. Pathol. Lab. Med. 100, 334-338 (1976)

29. Dubuc, P. U.: Basal corticosterone levels of young ob/ob mice. Horm. Metab. Res. 9, 95-97 (1976)

Received: August 2, 1978 ,

and in revised form: January 31, 1979

Michael C. Appel, Ph. D.

Departments of Anatomy and Pathology

University of Massachusetts Medical School

55 Lake Avenue, North

Worcester, MA 01605

USA 